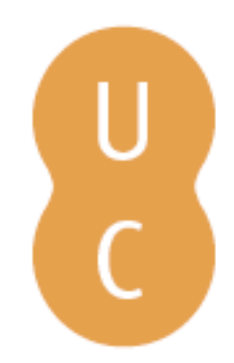

\title{
Rompalina
}

\section{Multi-criteria sustainability classification of dairy farms in a portuguese region}

Autor(es): $\quad$ Silva, Sandra; Alçada-Almeida, Luís; Dias, Luís C.

Publicado por: Imprensa da Universidade de Coimbra

URL

persistente: $\quad$ URI:http://hdl.handle.net/10316.2/38161

DOI: $\quad$ DOI:http://dx.doi.org/10.14195/978-989-26-1039-9_15

Accessed : $\quad$ 26-Apr-2023 14:57:36

A navegação consulta e descarregamento dos títulos inseridos nas Bibliotecas Digitais UC Digitalis, UC Pombalina e UC Impactum, pressupõem a aceitação plena e sem reservas dos Termos e Condições de Uso destas Bibliotecas Digitais, disponíveis em https://digitalis.uc.pt/pt-pt/termos.

Conforme exposto nos referidos Termos e Condições de Uso, o descarregamento de títulos de acesso restrito requer uma licença válida de autorização devendo o utilizador aceder ao(s) documento(s) a partir de um endereço de IP da instituição detentora da supramencionada licença.

Ao utilizador é apenas permitido o descarregamento para uso pessoal, pelo que o emprego do(s) título(s) descarregado(s) para outro fim, designadamente comercial, carece de autorização do respetivo autor ou editor da obra.

Na medida em que todas as obras da UC Digitalis se encontram protegidas pelo Código do Direito de Autor e Direitos Conexos e demais legislação aplicável, toda a cópia, parcial ou total, deste documento, nos casos em que é legalmente admitida, deverá conter ou fazer-se acompanhar por este aviso. 
IMPRENSA DA UNIVERSIDADE DE COIMBRA

COIMBRA UNIVERSITY PRESS

\section{ASSESSMENT \\ METHODOLOGIES}

ENERGY, MOBILITY AND OTHER

REAL WORLD APPLICATION

\section{PEDRO GODINHO \\ JOANA DIAS}

EDITORS

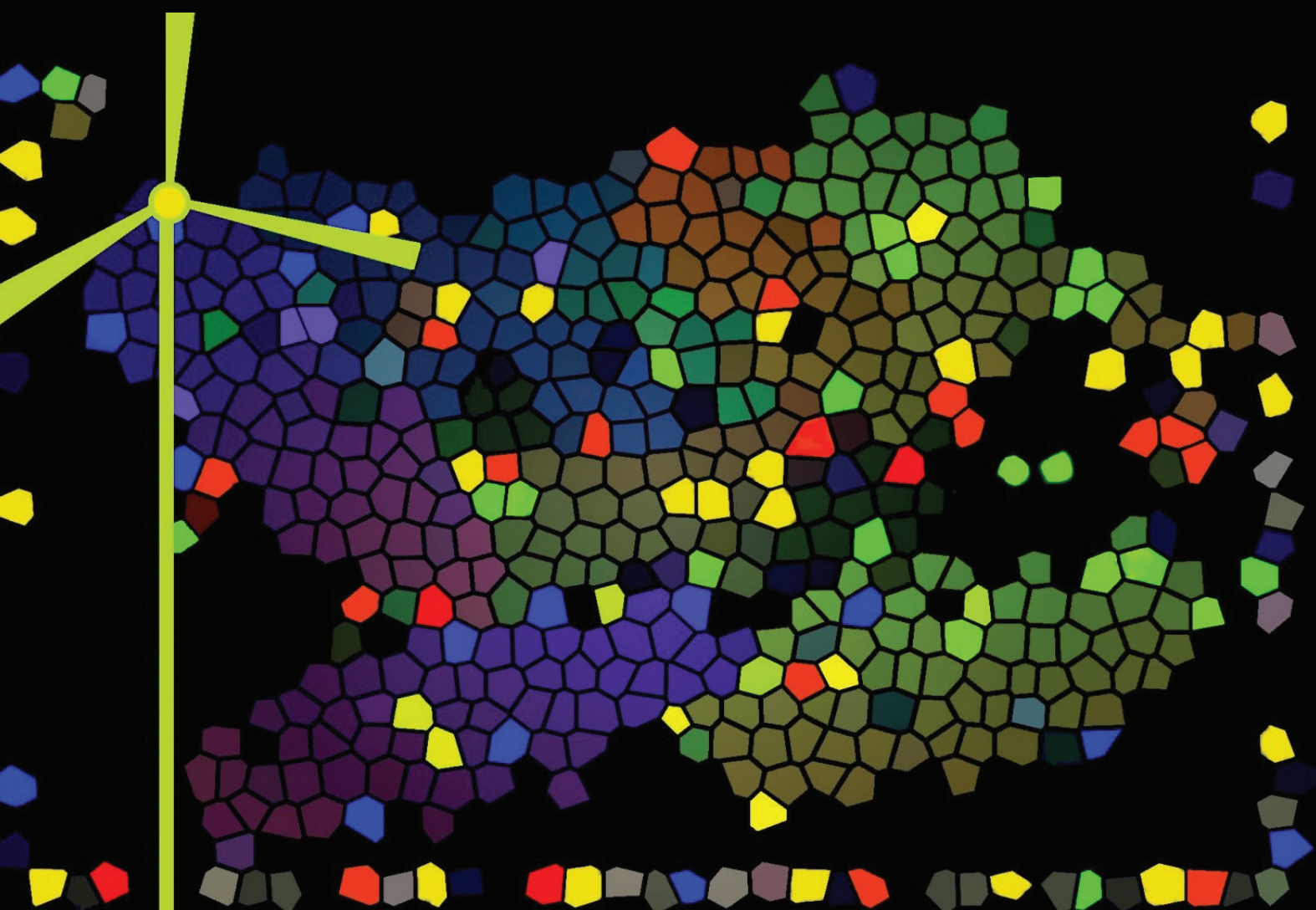




\title{
MULTI-CRITERIA SUSTAINABILITY CLASSIFICATION OF DAIRY FARMS IN A PORTUGUESE REGION
}

\author{
Sandra Silva ${ }^{1,2}$, Luís Alçada-Almeida ${ }^{2,3}$ and Luís C. Dias ${ }^{2,3}$
}

\begin{abstract}
:
This paper presents a Multi-criteria Decision Aid assessment of dairy farms sustainability in the Entre Douro e Minho region in Portugal. Sustainability is a multidimensional concept encompassing often conflicting economic, social and environmental points of view, potentially involving various stakeholders and decision makers. Seven environmental and seven socio-economic criteria were considered, aided by experts from different fields of knowledge. We used the multi-criteria classification method ELECTRE TRI to sort dairy farms into three categories, where socio-economic and environment viability were studied separately. The results were then combined to summarize the socio-economic and environmental viability according to four categories: Highly Sustainable, Moderately Sustainable, Marginally Sustainable and Not Sustainable. We used a Geographic Information System for better visualization and analysis of the spatial behavior of the classification obtained.
\end{abstract}

Keywords: Multi-criteria Decision Aiding; ELECTRE TRI; Geographic Information Systems; Agricultural Sustainability.

\footnotetext{
${ }^{1}$ Polytechnic Institute of Viana do Castelo

2 INESC - Coimbra, Institute for Systems Engineering and Computers

3 Faculty of Economics, University Coimbra

E-mails: sandrasilva@esa.ipvc.pt, alcada@fe.uc.pt, 1mcdias@fe.uc.pt
} 


\section{Introduction}

The concept of sustainability is defined in the Brundtland Report (UN, 1987) as "development which meets the needs of the present without compromising the ability of future generations to meet their own needs" arguing that sustainability is based on three distinct pillars: economic, environmental and social. Agricultural sustainability enhances the quality of life of the population through strengthening the economy, preserving cultural heritage, protecting natural resources, and increasing food security. The principles of sustainable development thus require that multiple dimensions are taken into account in sustainability assessment.

Multi-Criteria Decision Aiding (MCDA) methods are suitable for allowing the consideration of various dimensions associated with an assessment, involving decision makers and potentially other stakeholders in the evaluation process. This work presents an MCDA methodology for the classification of dairy farms, according to their sustainability, and presents an application to the Entre Douro e Minho (EDM) Region, in Portugal. Initially, environmental concerns and socio-economic concerns are classified independently. The results are later combined into a single classification for each farm: Highly Sustainable, Moderately Sustainable, Marginally Sustainable or Not Sustainable. To perform a classification the ELECTRE TRI MCDA method (Yu, 1992; Dias et al. 2002; Figueira et al. 2010) has been selected. A Geographic Information System (GIS) was used to present the results.

\section{Agricultural Sustainability and Multi-criteria Decision Aiding}

Agricultural sustainability requires monitoring the agricultural activities in order to prevent unsustainable behaviors and attitudes. It is necessary to integrate environmental, social and economic factors in the analysis, so that all actors involved can coordinate efforts in the quest for sustainability throughout all levels of the agricultural system. 
The way these dimensions are considered in the evaluation of sustainability varies among different authors. Some authors assume that an agricultural system is sustainable when the "trade-offs" between the objectives considered for evaluation of its performances (economic, social and environmental) reach acceptable values for the society as a whole (Becker, 1997; Hediger, 1999; Stoorvogel et al., 2004). This approach to agricultural sustainability becomes possible, while using aggregation methods to cover the three dimensions mentioned, by aggregating the set of criteria or indicators into a multidimensional simple or composite indicator. This approach has been used by several authors as Stockle et al. (1994), Andreoli and Tellarini (2000), Rigby et al. (2001), van Calker et al. (2005), Sydorovych and Wossink (2008) and Dillon et al. (2010).

However, the quantification of sustainable agriculture through a set of indicators is difficult to interpret and often criticized (Hansen, 1996; Munda, 2005; Gómez-Limón and Riesco, 2009), especially for:

1. the subjectivity of these methods (the choice of functional forms for the aggregation and weighting of the individual indicators);

2. the compensability usually aggregates the different dimensions of sustainability attributes (additive aggregation approaches) in spite of their theoretical incommensurability;

3. not facilitating the process of establishing cause-effect relationships between diverse system properties and therefore not providing mechanisms for diagnosing causes of unsustainability, or for evaluating effects of proposed interventions.

Taking into account the characteristics that are desired in this kind of evaluation, we consider that not all aggregation methods would be appropriate. For example, the requirement of non-compensation seems to be essential to avoid that a bad performance in one criterion would be cancelled by a good performance in another criterion. Thus, it was considered more appropriate to use non-compensatory methods based on the outranking concept. The outranking approach seemed more appropriate because, although it is less familiar to decision makers (compared to a weighted sum) and it requires more configuration parameters, it presents the following advantages: 
- it is not compensatory and therefore compatible with the requirements demanded by the concept of sustainability;

- it introduces the relation of incomparability, useful to account for situations in which the decision maker and/or the analyst are not able to compare two actions, which can happen in the sustainability analysis;

- it enables the usage of incomplete value information and, for example, judgments on ordinal measurement scale. In the classification of sustainability, the type of information that exists may be quite diverse as it comes from various fields (economic, social and environmental) with different scales and measures.

The sustainability classification of dairy farms has been framed as a sorting problem (Roy, 1985), because there is no need to compare the farms among themselves (furthermore, the high number of farms - 1705 - is not adequate for that purpose), but there is need to compare the farms to predefined targets. ELECTRE TRI, which is a widely used MCDA Outranking Method, has been chosen because, as a multi-criteria sorting method, it classifies alternatives (dairy farms) according to preference-ordered categories.

The use of multi-criteria methods to assess and determine the sustainability of agriculture is still scarce. Raju el al. (2000) used ELECTRE TRI and other MCDA techniques for sustainable water resources planning. Antunes et al. (2011) present the development of a participatory multi-criteria analysis process using AHP (Analytic Hierarchy Process) and SMCE (Social Multi-Criteria Evaluation) to evaluate irrigation management alternatives. van Calker et al. (2006) applieed MAUT (Multi-Attribute Utility Theory) to assess economic, social and ecological sustainability of Dutch dairy farms. Dantsis et al. (2010) applied MAVT (Multi-Attribute Value Theory) to evaluate and compare the level of sustainability of farms in two Greek regions. Gómez-Limón and Riesco (2009) and Santos (2011) applied AHP to the evaluation of agricultural sustainability. Lebacq et al. (2013) review typologies of sustainability indicators that have been developed at the farm level and present a case study to help users to select a set of indicators. 


\section{Outranking Method - ELECTRE TRI}

The outranking approach is based on pairwise comparisons between potential actions or alternatives using a binary, so-called, outranking relation (Roy, 1996): one action outranks another action if the former is considered "not worse than" ("at least as good as") the latter. ELECTRE methods comprise the construction of one or several outranking relation(s) comparing pairs of actions in a comprehensive way, followed by an exploitation procedure (Figueira et al., 2005).

The ELECTRE TRI method (Yu, 1992) provides a complete sorting of the alternatives of a set of alternatices A into two or more ordered categories $C_{i}, i=1, \ldots, k$, where $C_{1}$ is the worst (least desirable) category and $C_{\mathrm{k}}$ the best one. In order to define the categories, ELECTRE TRI uses some reference alternatives (reference profiles) $b_{i}, i=1, \ldots, k-1$, which can be real or hypothetical alternatives. Each reference profile $b_{i}$ is simultaneously the upper bound of category $C_{i}$ and the lower bound of category $C_{i+1}$. The assignment of each alternative $a \in A$ to a category is done by comparing it to the reference profiles. Among different ELECTRE TRI variants, we use the pessimistic (pseudo-conjunctive) procedure (Figueira et al. 2010). Each alternative is assigned to the highest category for which that alternative outranks its lower bound in the reference profile: $a$ belongs to $C_{1}$ if it does not outrank $b_{1}$, it belongs to $C_{2}$ if it outranks $b_{1}$ but it does not outrank $b_{2}$, etc.

ELECTRE TRI requires several parameters such as preference $\left(p_{j}\right)$, indifference $\left(q_{j}\right)$ and veto $\left(v_{j}\right)$ thresholds, and weight-importance coefficients $\left(w_{j}\right)$. Weight-importance expresses the relative importance of the criteria; indifference is the largest difference in performance, for a factor, that may be considered insignificant; preference is the smallest difference in performance constituting a clear advantage and the veto threshold indicates a difference in performance (discordance) so large that it vetoes an outranking, even if all other criteria agreed to it.

Each outranking relation is established in four steps: criteria concordance indexes and global concordance indexes calculation; discordance index calculation; credibility degree calculation; and establishing the 
outranking relation through the cutting level $(\lambda \in[0.5,1])$, that is defined as the lowest degree of credibility required to assign an alternative to a specific category. For further details on the algorithm and concepts of this method, see: Yu (1992), Roy and Bouyssou (1993), Roy (1996), Mousseau and Dias (2004), and Figueira et al. (2005, 2010).

\section{Case Study}

\subsection{Characterization of Dairy Farms}

The study area is corresponds to the Primary Dairy Basin in the EDM Region located in the Northwest Region of Portugal and it consists of 10 counties: Viana do Castelo, Barcelos, Esposende, Póvoa de Varzim, Vila Nova de Famalicão, Vila do Conde, Santo Tirso, Trofa, Matosinhos and Maia.

The 1705 dairy farms analyzed in this study are mainly located across the region of Barcelos (35\% of total), Vila do Conde (21\%), Póvoa de Varzim (12\%) and Vila Nova de Famalicão (9\%). Together, these farms comprise a total of 106,958 animals. Barcelos (32\% of the animals), Vila do Conde (25\%) and Póvoa do Varzim (14\%) are the counties with more animals.

The total area of farms in the study measures 20.331,00 hectares (ha), of which 17.318 ha are Land Area Under Agricultural Production (LAUAP). The average physical dimension of the total area of each dairy farms is 12 ha.

\subsection{Criteria Selection}

Many authors have analyzed the criteria (variables) that explain the processes of transformation of agricultural production structures. Although their conclusions do not coincide necessarily, they generally reinforce three factors that are unanimously considered influential in the possible paths of structural adjustment (expansion or early abandonment of agricultural activity): the political and economic factors, the producer 
(or farmer) and his family, and also the adaptation to environmental requirements (Santos, 2011).

Sustainable livestock systems should indeed be environmentally friendly, economically viable for farmers, and socially acceptable, notably for animal welfare. In this work, the criteria are divided into two dimensions: socio-economic and environmental. The definition and evaluation of performance criteria involved two experts from Environmental and Zoo-technic fields for the environmental dimension and one expert from Agro-Economic field for the socio-economic dimension. In defining the criteria, the experts took into account the new rules for bovine licensing, the Code of Good Agricultural Practices, Manual Fertilization of crops and Water Act, and the European legislation and recommendations.

Our study focuses on data-driven assessments carried out at farm level, from available databases. For the construction of the criteria, the database obtained from the survey developed during the implementation of the Basin Plan Land Dairy Primary Entre Douro and Minho (POBLPEDM, 2007) was considered, which is the most recent and comprehensive survey developed in the region. The survey covers some environmental, social and economic issues of dairy farms; but, not having been developed with the aim of evaluating dairy farms sustainability, it does not have all the information that would be ideal to perform a complete economic and environmental analysis. Financial and economic data as net revenue and equity to debt are not available. Still, we consider (along with the experts consulted) that, despite not include the ideal set of criteria, it would be sufficient to illustrate the methodology developed in this case study.

\subsubsection{Socio-Economic Criteria}

For an analysis of farmers, Ondersteijn et al. (2003) points out in the first place the management capabilities of the producer, saying that they rely on a set of personal characteristics such as their influences, motivations, skills or biographical factors, age (SE1 criterion in Table 1), time dedication to work (evaluating the situation of professional activity - SE2 criterion) and also the professional development of the producers (indicating their interest in updating and acquiring new knowledge to 
apply to their operation - SE3 criterion). It is the producer who makes substantive decisions such as those related to the production system investments. The characterization of farmers and the important role that their families play in the management and the activities of the project are very important.

The importance of family is related to the family tradition in this business, considering the involvement of its members and the consequent existence of successors who demonstrate interest and dedication to farming (SE4 criterion). Ochoa et al. (2007) discuss the importance of the succession of generations in agriculture in order to maintain the activity. Furthermore, the farmer's (and their family) income earned out of their dairy farming activity indicates dependence and consequently a need for business continuity (SE5 criterion).

Since dairy farming is still a particularly demanding activity in terms of investment in infrastructures and facilities, machinery and effective force, there can be an obstacle to maintain the motivation for new investments (SE6 criterion). Finally, it is important analyse the future perspectives (shutdown, decrease, relocate, stabilize and increase) of the producer regarding growth and business continuity (SE7 criterion).

The seven socio-economic criteria established are summarized in Table 1 (for more details see Silva, 2015).

Table 1: Socio-Economic Criteria and their Objectives.

\begin{tabular}{lcl}
\hline ID & Socio-Economic Criteria & Objective \\
\hline SE1 & Producer's Age & Minimize \\
SE2 & Professional Dedication (\%) & Maximize \\
SE3 & Professional Development & Maximize \\
SE4 & Successors & Maximize \\
SE5 & External Income & Minimize \\
SE6 & Investment Strategies & Maximize \\
$S E 7$ & Future Perspectives & Maximize \\
\hline
\end{tabular}

\subsubsection{Environmental Criteria}

In the more intensive systems that dominate dairy production, the main environmental issues are nutrient contamination of soil, groundwater and 
air pollution. The main impact is on soil integrity which is affected by increased use of fertilizers, feed additives and the more concentrated use of waste products such as manure. Other impacts derive from the pollution of groundwater with nitrates, pesticides and contaminated surface water. The impact of dairying on the atmosphere arises from de-nitrification, the production of methane, ammonia volatilization and carbon dioxide.

Consumers and society in general have forced the introduction of new attitudes with regard to questions of dairy production in particular, such as animal welfare, environmental impact and traceability and food health and safety regulations.

Thus, in the environmental dimension, seven criteria are considered that are defined on the one hand, in accordance with legal requirements and, on the other hand, with good practice to be implemented, referring to the cross-compliance, i.e. compliance with standards such as environmental health and animal-well-being, maintaining the land in good agricultural and environmental conditions, and respecting the rules on public health and pollution. These are summarized in Table 2 .

Table 2: Environmental Criteria and their Objectives.

\begin{tabular}{lcl}
\hline ID & Environmental Criteria & Objective \\
\hline$E 1$ & Storage Capacity of Manure & Maximize \\
$E 2$ & Number of Livestock units per area of manure application & Minimize \\
$E 3$ & Excess on nitrogen balance & Minimize \\
$E 4$ & Total Production of Greenhouse Gases & Minimize \\
$E 5$ & Percentage of Storage Structures Near Water Lines & Minimize \\
$E 6$ & Percentage of Individualized Collection of Rainwater & Maximize \\
$E 7$ & Animal Well-being & Maximize \\
\hline
\end{tabular}

The first criterion (E1) concerns the farm's capacity to store manure produced by its animals and is based on the total storage capacity of effluents $\left(\mathrm{m}^{3}\right)$ and the number of standard livestock units (LU), according to rules for licensing bovine farming. The E2 criterion takes into account the amounts allowed for the incorporation of organic nitrogen in the soil in terms of LU/LAUAP, according the Wastewater Management Plan. The E3 criterion determines the excessive incorporation of nitrogen excreted 
in relation to the forage area. The $\mathrm{E} 4$ criterion defines the production of greenhouse gases acoording the production of milk of each dairy farm. The E5 criterion addresses the risk of contaminating water lines and consists of the ratio between the number of storage points less than 25 meters away from the water lines and the total number of existing storages on the farm. The E6 criterion addresses the use of water and consists of the proportion of the farms' storage facilities that have individualized collection of rainwater, that increases the effectiveness of storage capacity, provides fertilizers of better quality, reuses water, and thereby reduces the water burden. The $\mathrm{E} 7$ criterion concerns animal well-being, assessed by considering the ratio between the covered area (stall) and the number of cows on the farm. For more details on these criteria see Silva (2015).

\subsection{Application of the ELECTRE TRI Method}

ELECTRE TRI is a suitable MCDA method in sorting problems, as addressed in this case study of dairy farms classification according to their environmental and socio-economic viability. In a classification of dairy farms in which social, economic and environmental aspects are at stake, it is often important to use known standards (references profiles defined in legislation) to define various categories.

ELECTRE TRI assigns a set of alternatives to a group of predefined categories, considering multiple criteria. In this work, the set of alternatives are dairy farms and the predefined categories consist of three viability levels: Not Viable (Category 1), Barely Viable (Category 2) and Viable (Category 3). We study the environmental and socio-economic viability separately due to the distinct nature of these two areas, and then derive a broader perspective on sustainability.

The ELECTRE TRI method performs the assignment of each alternative to a category, based on how its performances compare with the reference profiles. We define two reference profiles $b_{1}$ and $b_{2}$, where $b_{2}$ indicates the minimum performance standards that a farm should have in order 
to be placed in Category 3 and $b_{1}$ indicates the minimum performance standards in order to be in Category 2. The profiles (Table 3) have been defined by experts.

Table 3: References Profiles $\left(b_{1}\right.$ and $\left.b_{2}\right)$ for the Environmental and Socio-Economic classification using the ELECTRE TRI method.

\begin{tabular}{|c|c|c|c|c|c|}
\hline \multicolumn{6}{|c|}{ ENVIRONMENTAL } \\
\hline $\mathrm{E} 2$ & $\mathrm{E} 2$ & $\mathrm{E} 4$ & E5 & E6 & E7 \\
\hline 1.0 & 0 & 1000 & 0.25 & 0.5 & 5.0 \\
\hline 1.3 & 300 & 4000 & 0.50 & 0.2 & 2.5 \\
\hline
\end{tabular}

\begin{tabular}{c|lllllll|}
\multicolumn{8}{c}{ SOCIO-ECONOMIC } \\
\cline { 2 - 8 } & SE1 & SE2 & SE3 & SE4 & SE5 & SE6 & SE7 \\
$b_{1}$ & 50 & 4 & 3 & 4 & 2 & 1 & 4 \\
$b_{1}$ & 65 & 2 & 0 & 2 & 4 & 0 & 1 \\
\cline { 2 - 8 } & & & & & &
\end{tabular}

Table 4: Environmental and Socio-Economic Thresholds of the ELECTRE TRI method: indifference $\left(q_{j}\right)$, preference $\left(p_{j}\right)$, and veto $\left(v_{j}\right)$ thresholds, and weight-importance coefficients $\left(w_{j}\right)$.

\begin{tabular}{c|lllllll|}
\multicolumn{7}{c}{} & \multicolumn{7}{c}{ ENVIRONMENTAL } \\
\cline { 2 - 8 } \multicolumn{1}{c}{} & E1 & E2 & E3 & E4 & E5 & E6 & E7 \\
$q_{j}$ & 0.10 & 0.10 & 100 & 300 & 0.05 & 0.10 & 1 \\
$p_{j}$ & 0.20 & 0.20 & 150 & 800 & 0.10 & 0.20 & 2 \\
$v_{j}$ & 0.50 & 0.50 & 500 & 6000 & 0.55 & 0.45 & 3 \\
$w_{j}$ & 0.20 & 0.20 & 0.20 & 0.05 & 0.15 & 0.05 & 0.15 \\
\cline { 2 - 8 } & & & & & &
\end{tabular}

SOCIO-ECONOMIC

\begin{tabular}{c|lllllll|}
\cline { 2 - 8 } \multicolumn{1}{c}{} & SE1 & SE2 & SE3 & SE4 & SE5 & SE6 & SE7 \\
$q_{j}$ & 10 & 1 & 1 & 1 & 1 & 0 & 1 \\
$p_{j}$ & 15 & 2 & 2 & 2 & 2 & 0.5 & 2 \\
$v_{j}$ & 20 & 4 & 3 & 4 & 3 & 1 & 3 \\
$w_{j}$ & 0.2 & 0.1 & 0.1 & 0.2 & 0.1 & 0.15 & 0.15 \\
\cline { 2 - 8 } & & & & & & &
\end{tabular}

Taking into account the inaccuracies and uncertainties in the performances of the alternatives, thresholds of indifference $\left(q_{j}\right)$ and preference $\left(p_{j}\right)$ were defined for each criterion, in order to better model the preferences of the decision makers. The veto threshold $\left(v_{j}\right)$ that is used in the discordance test was also determined for each criterion, as well as the weight $\left(w_{j}\right)$ of each criterion that is used in the concordance test (Table 4). We calculated the partial concordance index for each of the criteria and then the comprehensive concordance indices of global agreement that indicates how much is the performance of the alternatives consistent with " $a$ outranks $b_{i}$ ", i.e. $a S b_{i}$. Most of the criteria (sum of weights 
above the cutting level) should be in favor of this statement. Next, we calculated the discordance indexes for each criterion, representing the statement opposed to $a S b_{i}$.

Finally, the credibility index $\left(\sigma\left(a, b_{i}\right)\right)$ was calculated, which determines how credible the statement $a S b_{i}$ is according to the comprehensive concordance and discordance indexes. For the classification procedure it was also necessary to define a cutting level $(\lambda)$, in this case $\lambda=0.6$, to determine the binary relationship between the alternatives and reference profiles, such that: $a S b_{i} \Leftrightarrow \sigma\left(a, b_{i}\right) \geq \lambda$. The cutting level indicates that $60 \%$ of the criteria (considering their weights) have to agree in order to assign an alternative to a specific category.

Individual meetings were held with each expert, where the method was presented and the values of its parameters were elicited.

\section{Results}

A Web Multicriteria Spatial Decision Support System (Web MC-SDSS) named ELECTRE TRI in ArCGIS has been applied in this work (for details see Silva et al., 2014) to classify the environmental and socio-economic viability of dairy farms, obtaining the results presented in Figure 1 and the map with the viability classification.

Concerning environmental viability, we conclude that the majority $(60 \%)$ of dairy farms are classified as Environmentally Not Viable (Category 1). On the other hand, the assessment of the Socio-economic Viability, considering the defined criteria, indicates that only a small minority (3\%) is classified as Not Viable. The analysis of Figure 1 shows that environmental issues are those that mostly affect the viability of dairy farms in the EDM Region, for non-compliance with environmental requirements. Another important aspect is the noticeable difference between the classifications obtained in the evaluation of Environmental and Socio-economic Viability of farms. Let us note that these two dimensions are not completely independent: a farm could improve its environmental condition by making more investments, at the cost of hindering its economic condition, unless 
subsidies or other incentives were made available (unfortunately in the current situation of this region such investments are not likely). Thus, the classification Environmentally Not Viable should be understood as meaning that a farm is hardly viable due to its environmental condition.

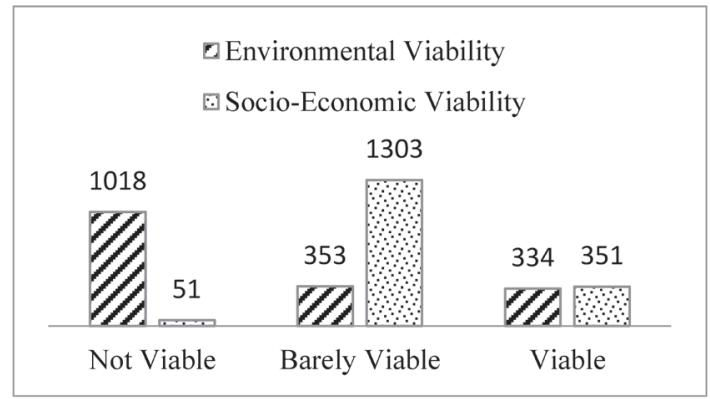

Figure 1: Number of farms classified in each category.

Table 5 compares the classifications obtained according to Environmental Viability and the Socio-economic Viability. Only 2\% (30) of the dairy farms are classified as Environmentally Not Viable and Socio-economically Not Viable; $16 \%$ (271) of the farms are classified as Barely Viable, considered to be environmental and Socio-economic Barely Viable simultaneously. Only 3\% (48) of the farms are classified as Viable according to the Environmental and the Socio-economic perspectives. The largest group, with $44 \%$ (754) of the total number dairy farms, is classified as both Socioeconomically Barely Viable and Environmentally Not Viable.

Table 5: Cross tabulation of the classification of Environmental and Socio-Economic Viability.

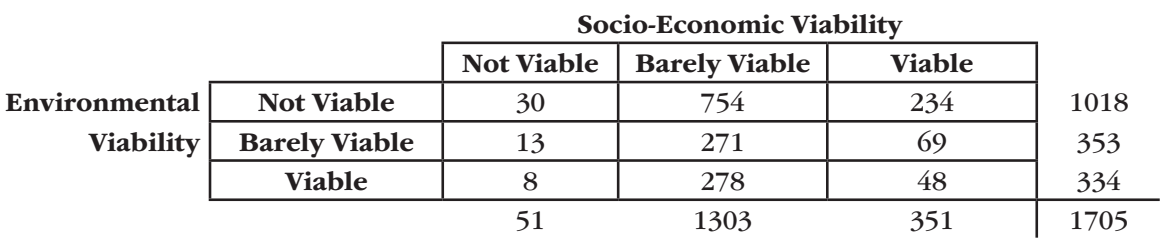

After obtaining these results, the experts were again involved in a new discussion and analysis, considering that in order to conduct the 
evaluation of a farm as to the overall Sustainability, it would make sense to reclassify (or sub-divide) the categories obtained in the study of Environmental and Socioeconomic Viability into the following new set of categories:

Highly Sustainable - dairy farms classified as Viable on Socio-Economic and Environmental Viability, simultaneously;

Moderately Sustainable - dairy farms classified as Barely Viable in Environmental Viability and Socio-Economic Viability in Viable or vice versa;

Marginally Sustainable - dairy farms classified as Barely Viable in Environmental and Socioeconomic Viability;

Not Sustainable - all other.

This reclassification yields the results depicted in Figure 2.

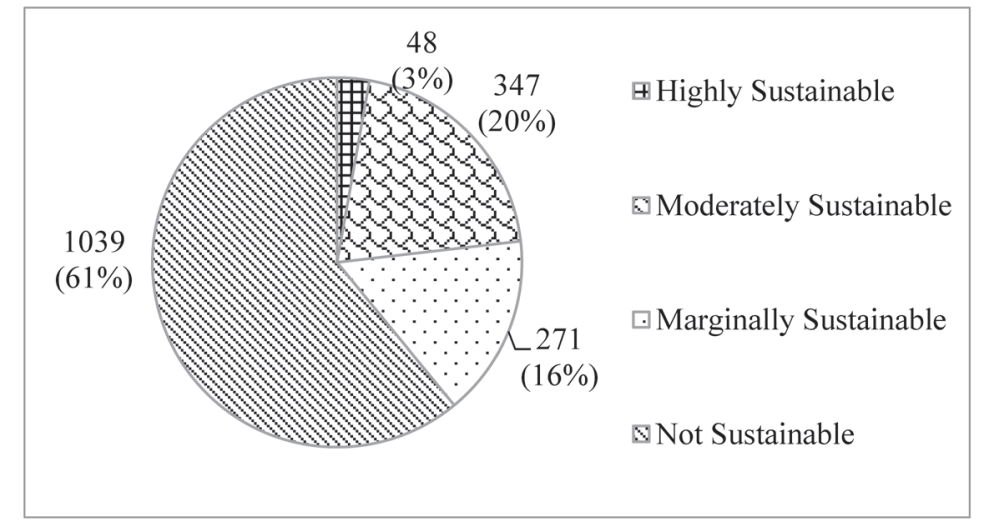

Figure 2: Number and percentage of dairy farms classified in each of four categories of Sustainability

Figure 3 presents the corresponding kernel density maps for a better visualization of the distribution of the density of each of these four categories. The Kernel Density (available in ArcGIS software) consists in an interpolation which is intended to generate a continuous surface through sample points (in this case, exploits), which is determined by number of farms classified in each category in relation to the area $\left(\mathrm{km}^{2}\right)$. 


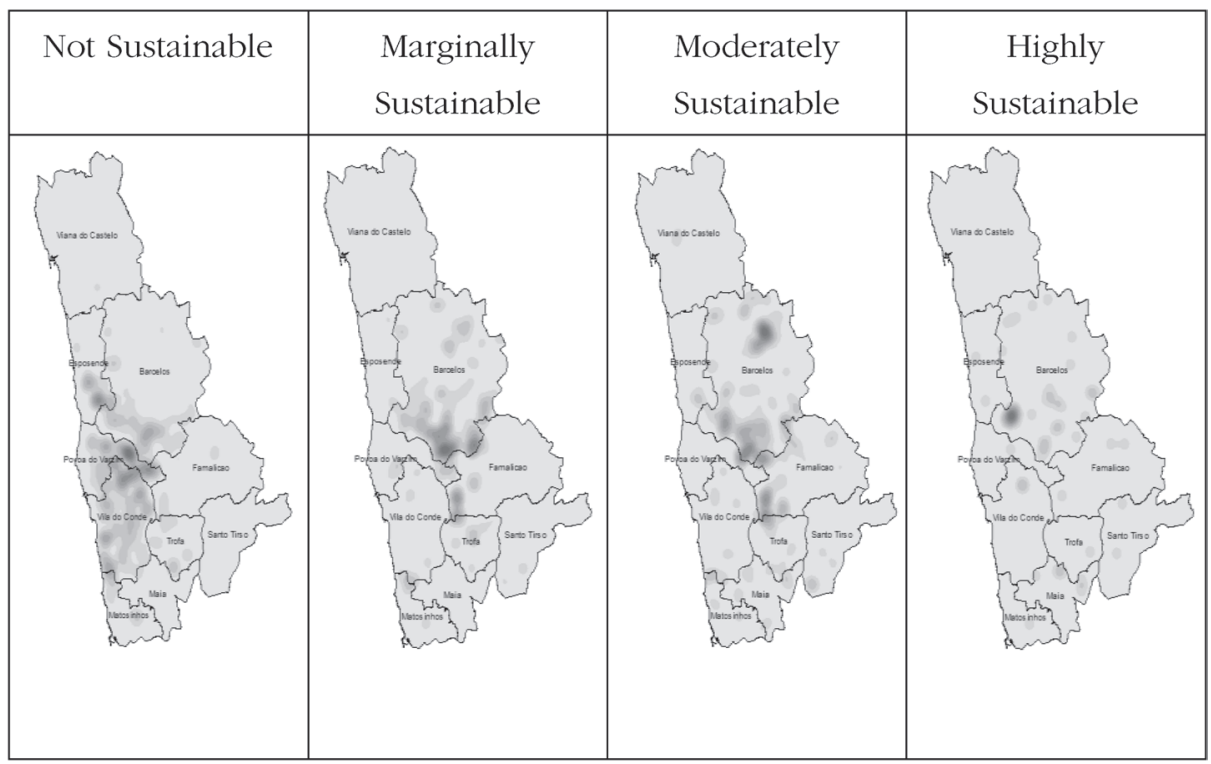

Figure 3: Density of distribution of dairy farms according to the new (aggregated) perspective of Sustainability

Analyzing briefly the spatial distribution of the sustainability classification, we can highlight the following: about $90 \%$ of the dairy farms in the county of Vila do Conde are classified as Not Sustainable, as well as $88 \%$ of the dairy farms in Póvoa de Varzim and $82 \%$ of those in Esposende - which are very high percentages. The counties of Maia, Santo Tirso and Barcelos are those with better classifications: there is a higher percentage of farms classified as Highly Sustainable and the lowest percentage of dairy farms classified as Not Sustainable (but still around $40 \%$ ). The dairy farms classified as Not Sustainable, have in general a high animal density and reduced dimensions, and have difficulties in growth due to their proximity to urban areas. In turn, in dairy farms classified as High Sustainable there is a better fit between the number of animals and their dimension but especially they have improved environmental conditions. 


\section{Sensitivity Analysis}

Setting the required input data for the ELECTRE TRI method (weights, thresholds of indifference and preference, veto, reference profiles and cutting level) is a complex and ambiguous task because of the associated uncertainties. To check how changes in the parameters influence the results, we performed a sensitivity analysis, considering different scenarios, in order to verify the robustness of the results.

Two scenarios were defined, in order to develop a sensitivity analysis in the study of Environmental and Socio-economic Viability, which we will call the Benevolent and Stringent scenarios. These scenarios are characterized by a variation of $5 \%$ in the profiles of the categories, in the preference, indifference and veto thresholds and in the cutting level (there was no change in the weights in any of the scenarios). We aim at evaluating changes in the results obtained in these two scenarios when compared with the classification of originally obtained data, which we shall call the Original scenario.

The Benevolent Scenario is characterized by changing the parameters of the ELECTRE TRI method as follows: the cutting level is decreased by 0.03 (becoming 0.57), the reference profiles of the categories increase $5 \%$ if a criterion is to be minimized and decrease $5 \%$ if a criterion is to be maximized, and thresholds of preference, indifference and veto are increased by $5 \%$. This is a less demanding scenario than the Original one.

In turn, the Stringent Scenario considers the changes referred to in the following parameters of the ELECTRE TRI method: the cutting level is increased by 0.03 (becoming 0.63 ), the reference profiles of the categories decrease $5 \%$ if the criterion is to be minimized, and increase $5 \%$ if a criterion is to be maximized, and thresholds of preference, indifference and veto are decreased by $5 \%$. This is a more demanding scenario than the original one.

The results of comparing the three scenarios are summarized in Figure 4. 
Category 1 QCategory 2 Category 3

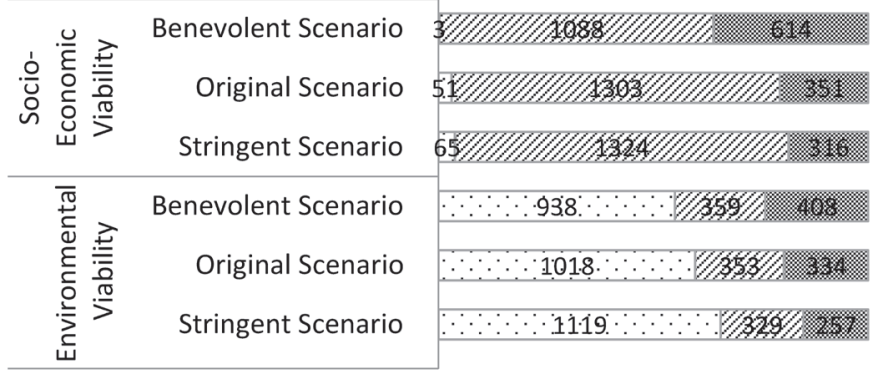

Figure 4: Comparison of the three scenarios regarding the classification of Socio-Economic and Environmental Viability (Category 1 - Not Viable, Category 2 - Barely Viable, Category 3 - Viable).

In the Stringent Scenario, the percentage change in the socio-economic assessment is lower than in the environmental assessment. The percentage change in each category is equal to or less than the variation caused in the parameters and, as such, it can therefore be said that despite the change in the final results this is not very relevant.

In the Benevolent Scenario, it is noted that the number of dairy farms changing classification in environmental analysis is less than the number changing in the socio-economic analysis. This means that, even when requiring less compliance with environmental requirements, no major changes in the classification of farms are visible. Despite the fact that there were some changes obtained in the classification, those were not very significant.

We considered also other Stringent and Benevolent scenarios characterized by a greater variation: $15 \%$ in the profiles of the categories, in the preference, indifference and veto thresholds and cutting level (becoming 0.51 in Benevolent and 0.69 in Stringent scenarios). In both new Stringent and Benevolent scenarios the changes in the classification, in all four sustainability categories, is less than percentage change, not exceeding 7\%, compared with results of Original scenario. In Figure 5, it is possible compare the number of dairy farms classified in each of four categories of Sustainability for the 5 scenarios analysed: Stringent 
(5\% and 15\%), Original and Benevolent (5\% and 15\%) scenarios. These different scenarios considered support the stability of the results obtained by ELECTRE TRI method.

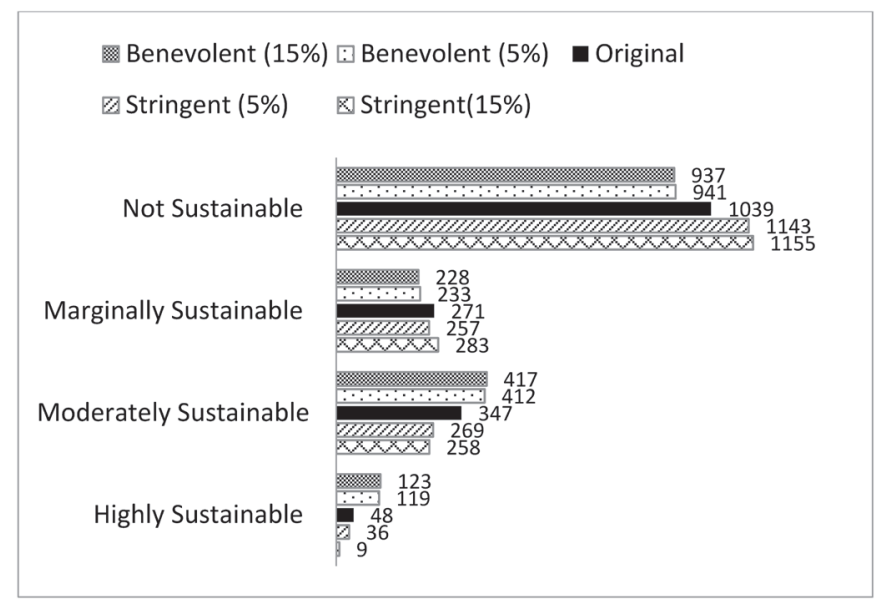

Figure 5: Number of dairy farms classified in each of four categories of Sustainability by comparing the five scenarios.

\section{Discussion}

Considering the results, one notes the worrying situation in which many farms in the EDM Region are found regarding their sustainability. In this region, the economic component contributes greatly to the sustainability of farms, but the breach of environmental requirements is having a greater influence on their sustainability. There are reasons, natural and historical, which tend to hinder the resolution of environmental problems, such as the ownership structure of dairy farms and their dispersion, the morphological and geological nature of the terrains and the proximity to urban areas. The solution to this environmental problem is an evolution of the structure of dairy farms to reduce the intensity of production, but also for obtaining dimension which will amortize investments in equipment and training. However, the economic framework is itself heavily influenced by the nature of the support regime (largely price support), 
technology development and structural change in the production sector (plus structural change in the upstream and downstream supply chain). So it is necessary to find diverse environmentally and economically sustainable solutions, for those farms that are moderately or marginally sustainable. As for the farms that are not sustainable, although solutions should be sought to enable the continuation of the dairy farming activity, a reconversion to a different activity is also an alternative to consider.

For this study, the ELECTRE TRI method seemed appropriate as it sorts alternatives (dairy farms) by preference-ordered categories. Indeed, in classification of dairy farms, where various environmental, economic and social aspects are at stake, it is often important to use known standards (reference profiles) to define various categories of sustainability. This requires capability of evaluating each farm in absolute terms, not just in comparison with other peers, as well as the need to include evaluation aspects expressed in different units, using any type of scales (including qualitative). The ELECTRE TRI refuses the possibility of total compensation between the alternative's performances on the criteria. Thus it prevents that a farm with very good performance on some criterion compensates a very poor performance on another criterion and achieves the best category despite that major weakness.

Finally, the sensitivity analysis developed verifies the robustness of the results of dairy farms sustainability assessment.

\section{Conclusions}

The complexity of sustainability assessment can be mitigated with the use of MCDA techniques. In this study, we found that MCDA can be useful in the evaluation of sustainability that encompasses multiple dimensions. The Outranking Method ELECTRE TRI proved to be an adequate method, preventing unwarranted compensation of poor performances, and yielding a classification of dairy farms on sustainability according to the parameters and values assigned by experts. The integration of GIS capabilities and MCDA techniques reinforces the advantages of both tools. 
The main highlights of the methodology followed in this paper are the following. First, the sustainability assessment is based explicitly on multiple criteria, rather than trying to find an indicator such as carbon footprint or a financial ratio that would synthetize environmental and economic sustainability, respectively. Second, the evaluation is grounded on a classification method which is parsimonious in terms of the value judgments it requires, namely not requiring substitution rates among the criteria, nor pairwise comparisons among a large number of alternatives. Although the results are somewhat coarse (when compared to a full ranking), classification results are familiar and widely accepted by decision makers (e.g., efficiency labeling). Third, a separate assessment of sustainability dimensions is made, directing attention to different potential weaknesses of the farms. Nevertheless, these two dimensions of sustainability can be conveniently summarized into an easy to understand overall classification, namely to present graphically in maps.

In this work it was also possible to analyze the geographical distribution of the classification of dairy farms and to realize that the areas which reflect higher levels of sustainability are those that have an increasing concentration of farms, whereas areas that reflect the worst levels of sustainability are those that are subject to abandonment.

The structure, process and application of sustainability assessment can be extended to other areas besides agriculture. In this decision process, options were taken in each phase, which leave space for future studies and the development of new approaches, such as the aggregation of these or other criteria, with the involvement of more experts with the application of other(s) multi-criteria method(s), with application for more updated reinvestigation.

\section{References}

Andreoli, M., Tellarini, V., 2000. Farm sustainability evaluation: methodology and practice. Agriculture, Ecosystems and Environment, 77(1): 43-52. 
Antunes, P., Karadzic, V., Santos R., Beça P., Osann, A., 2011. Participatory multi-criteria analysis of irrigation management alternatives: the case of the Caia irrigation district, Portugal. International Journal of Agricultural Sustainability, 9(2): 334-349.

Becker, B., 1997. Sustainability assessment: a review of values, concepts, and methodological approaches. Consultative Group on International Agricultural Research, The World Bank, Washington, D.C., 63 pp.

Dantsis, T., Douma, C., Giourga, C., Loumou, A., Polychronaki, E.A., 2010. A methodological approach to assess and compare the sustainability level of agricultural plant production systems. Ecological Indicators, 10: 256-263.

Dias, L., Mousseau, V., Figueira, J., Clímaco, J., 2002. An aggregation/disaggregation approach to obtain robust conclusions with ELECTRE TRI. European Journal of Operational Research, 138: 332-348.

Dillon, E. J., Hennessy T., Hynes, S., 2010. Assessing the sustainability of Irish agriculture. International Journal of Agricultural Sustainability, 8(3): 131-147

Figueira, J., Mousseau, V., Roy, B., 2005. Electre Methods. In: Figueira, J.; Greco, S.; Ehrgott, M. Multiple Criteria Decision Analysis: State of The Art Survey. New York: Springer, Cap. 4 .

Figueira, J.R., Greco S., Roy B., Słowinski R., 2010. ELECTRE methods: Main features and recent developments. In C. Zopounidis and P. Pardalos (Eds.), Handbook of Multicriteria Analysis, Chapter 4, New York, USA: Springer.

Gómez-Limón, J. A., Riesgo, L., 2009. Alternative Approaches to the construction of a composite indicator of agricultural sustainability: An application to irrigated agriculture in the Duero basin in Spain. Journal of Environmental Management, 90: 3345-3362.

Hansen, J.W., 1996. Is agricultural sustainability a useful concept? Agricultural Systems, 50(1): 117-143.

Hediger, W., 1999. Reconciling 'weak' and 'strong' sustainability. International Journal of Social Economics, 26:7/8/9, 1120-1143.

Lebacq, L., Baret, P.V., Stilmant, D. 2013. Sustainability indicators for livestock farming. A review. Agronomy for Sustainable Development, 33:311-327.

Mousseau, V., Dias, L., 2004. Valued outranking relations in ELECTRE providing manageable disaggregation procedures. European Journal of Operational Research, 156: 467-482.

Munda, G., 2005. Measuring sustainability: a multi-criterion framework. Environment, Development and Sustainability, 7(1):117-134.

Ochoa, A.M.A, Oliva, V.C, Sáez, C.A, 2007. Explaining farm succession: the impact of farm location and off-farm employment opportunities. Spanish Journal of Agricultural Research, 5(2): 214-225.

Ondersteijn, C.J.M., Giesen, G.W.J., Huirne, R.B.M., 2003. Identification of farmer characteristics and farm strategies explaining changes in environmental management and environmental and economic performance of dairy farms. Agricultural Systems, 78: 31-55.

POBlPEDM, 2007. Plano de Ordenamento da Bacia Leiteira Primária do Entre Douro e Minho. Escola Superior Agrária do Instituto Politécnico de Viana do Castelo, Instituto para o Desenvolvimento Agrário da Região Norte e Universidade do Porto - CIBIO.

Raju, K.S., Duckstein, L., Arondel, C., 2000. Multicriterion Analysis for Sustainable Water Resources Planning: A Case Study in Spain. Water Resources Management, 14: 435-456.

Rigby, D., Woodhouse, P., Young, T. and Burton, M., 2001. Constructing a farm level indicator of sustainable agricultural practice. Ecological Economics, 39(3): 463-478.

Roy, B., 1985. Méthodologie multicritère d'aide à la decision. Economica, Paris. 
Roy B., Bouyssou, D., 1993. Aide multicritère à la décision: méthodes et cas, Economica, Paris.

Roy, B., 1996. Multicriteria Methodology for Decision Aiding. Kluwer Academic Publishers.

Santos, J.C.S.M., 2011. Viabilidad de las explotaciones lecheras en un escenario de desconexión del apoyo y condicionalidad: Un estudio de caso en el noroeste de Portugal. Ph.D. Dissertation, Universidad Politécnica de Madrid, Escuela Técnica Superior de Ingenieros Agrónomos.

Silva, S., 2015. Sistema de Apoio à Decisão Espacial Multicritéio na localização de centrais de biogás. Tese de Doutoramento em Gestão-Ciência Aplicada à Decisão. Faculdade de Economia, Universidade de Coimbra.

Silva, S., Almeida-Alçada, L., Dias L., 2014. Development of a Web-based Multi-criteria Spatial Decision Support System for the assessment of environmental sustainability of dairy farms, Computers and Electronics in Agriculture, 108: 46-57.

Stockle, C.O., Papendick, R.I., Saxton, K.E., Campbell, G.S., van Evert, F.K., 1994. A framework for evaluating the sustainability of agricultural production systems. American Journal of Alternative Agriculture, 9(1-2): 45-50.

Stoorvogel, J.J., Antle, J.M., Crissman, C.C. and Bowen W., 2004. The tradeoff analysis model: integrated biophysical and economic modeling of agricultural production systems. Agricultural Systems, 80(1): 43-66.

Sydorovych, O., Wossink, A., 2008. The meaning of agricultural sustainability: Evidence from a conjoint choice survey. Agricultural Systems, 98(1): 10-20.

United Nations, 1987. Brundtland Report, Report of the World Commission on Environment and Development: Our Common Future, Oxford University Press.

van Calker, K., Berentsen, P., Romero, C., Giesen, G., Huirne, R., 2006. Development and application of multi-attribute sustainability function for Dutch dairy farming systems. Ecological Economics, 57: 640-658.

van Calker, K., Berentsen P., Giesen G., Huirne, R., 2005. Identifying and Ranking Attributes that Determine Sustainability in Dutch Dairy Farming. Agriculture and Human Values, 22: 53-63.

Yu, W., 1992. ELECTRE TRI: Aspects méthodologiques et manuel d'utilisation. Document du LAMSADE No. 74, Université Paris-Dauphine. 
Série Investigação

Imprensa da Universidade de Coimbra

Coimbra University Press

2015

mais

Programa Operacional Regional do Centro

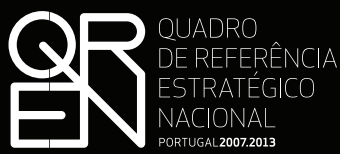

PORTUGAL 2007.2013

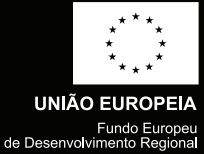

- $\mathbf{U}$

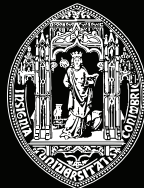

C •

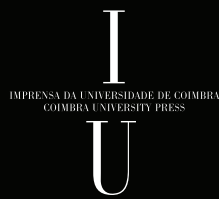

